\title{
Multiple Facets of Migration Research: Key Questions, Topics, and Avenues yet to Be Explored
}

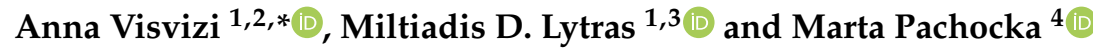 \\ 1 School of Business \& Economics, Deree College-The American College of Greece, 153-42 Athens, Greece; \\ mlytras@acg.edu \\ 2 Effat College of Business, Effat University, Jeddah P.O. Box 34689, Saudi Arabia \\ 3 Effat College of Engineering, Effat University, Jeddah P.O. Box 34689, Saudi Arabia \\ 4 SGH Warsaw School of Economics, Al. Niepodległości 162, 02-554 Warsaw, Poland; \\ marta.pachocka@gmail.com \\ * Correspondence: avisvizi@acg.edu
}

Received: 15 December 2019; Accepted: 24 December 2019; Published: 26 December 2019

check for updates

\begin{abstract}
Migration and its diverse forms, including economic migration, irregular migration, forced migration, as well as the plethora of factors that drive people's decisions to leave their habitat and seek fortune in new places, occupy a dominant position in contemporary research and political debate. Academic literature today brims with contributions elaborating on the complexities and implications of migration, thus not only opening several avenues of research, but also delivering in-depth insights into the phenomenon of migration. This notwithstanding, certain topics require greater attention of the research community if ways of navigating the complex challenges and opportunities specific to migration are to be identified. This overview offers some leads in this respect. Against this backdrop, this introduction also highlights that much more work needs to be done to trigger the momentum for the inclusion of information and communication technology (ICT) in migration research. A case is made that in times of the 4th industrial revolution the nexus between ICT and migration needs to be taken seriously.
\end{abstract}

Keywords: migration; sustainability; ICT; interdisciplinary migration research agenda

\section{Introduction: On the Relevance of the Topic}

Migration and its diverse forms, including economic migration, irregular migration, forced migration, and the plethora of factors that undermine people's decisions to leave their habitat and seek fortune in new places, occupy a dominant position in contemporary research and political debate [1-5]. At that debate unfolds, the aggregate term 'migration' has turned into a buzzword of popular discourse [1], with its key components, such as individual agency, an individual's suffering and success, the causal relationships defining individual decisions to move, regulatory frameworks, red tape, and transaction costs being-perhaps unconsciously—but, effectively, ontologically reduced in this debate. As a result, popular media depictions of migration either simplify it or offer a biased account of migration and migrants themselves [6,7].

On the positive side, prestigious journals brim with contributions elaborating on the complexities and implications of migration worldwide [8-12], thus not only opening several avenues of research, but also delivering in-depth insights into the phenomenon of migration. This notwithstanding, certain topics still require greater attention of the research community. The Rohingya crisis or the case of internally displaced persons (IDPs) in Yemen are just the most striking cases in this respect [13-15]; so is the Venezuela refugee crisis and many more. In some respects, the surge in migration research and the variety of contributions from diverse scholarly perspectives does just that [16]. Notably, we can talk 
of a substantial breakthrough as regards our thinking of the regulatory dimensions of migration. Here questions of asylum, asylum regimes, the right to protection, and, finally, the very question of varieties of approaches to (im)migration policies have been placed in the center of the conversation [17-24].

As the debate continues and a growing number of scholars call for a new research agenda in the field of migration $[1,2,21]$, the role that sophisticated information and communication technology (ICT) plays with regards to migration remains underdiscussed [25-27]. In this context, somewhat surprisingly, the nexus between cities and migration, and perhaps most prominently, between smart cities and migration remains opaque in the literature. The few existing contributions highlight just how much of an important research and policy-field it is [28,29].

Driven by these considerations, the objective of this Special Issue is to make a case that, regardless of the positive developments in the migration research, a vast field of research remains under-explored. Accordingly, the objective of this Special Issue is to encourage research that builds on the premises of an integrated inter- and multidisciplinary research agenda apt to capture the logic, dynamics, and mechanisms underpinning migration in the modern age. The key assumption underpinning this Special Issue was that our societies, and so decision-makers, can no longer pretend that migration does not concern them. All of us, in one way or another, are exposed to diverse forms of migration and their implications. Migration, in other words, and our societies' ability and capacity to deal with it responsibly, are a function of our societies' sustainability. Hence, the imperative is to embrace the logic specific to the sustainability debate and infuse the migration debate with it.

\section{Overview of the Special Issue}

The papers submitted to this Special Issue offer a brief insight into the complex matter of contemporary migration. Much more needs to be done if the research agenda that the call for papers delineated is to be populated and an in-depth discussion is to be ignited. The papers included in this Special Issue address five broad issue areas, including: (i) the EU member states capacity to respond to irregular migration; (ii) issues and challenges pertinent to irregular migration in the EU, such as questions of instrumentalization of migration, populism, economic cost of managing migration, and implementing integration policies, as well as our societies' mangling ability to face the challenge of migration; (iii) factors determining people's decision to leave their habitat; (iv) involuntary domestic migration, but not forced displacement; (v) social psychology of migration.

The 2015-2016 twin migration and refugee crises and their implications challenged the European Union and its member states in a variety of ways [30,31]. The relative inability to develop apt responses to the crisis situation revealed, on the one hand, that the existing regulatory frameworks designed to deal with immigration, and the right to asylum were ineffective, and on the other hand, that the EU member states were unable to talk to each other in view of addressing the multiple challenge together $[28,29]$. The case of Romania elaborated in this Special Issue by Vasile and Androniceanu [30] attests to that. In their paper titled 'An Overview of the Romanian Asylum Policies', the authors examine the state of the art of asylum policy in Romania. The authors make an interesting observation that the EU member states have been divided, not only on account of their stance toward migration, and specifically vis-à-vis the emergency relocation scheme, but also on account of their economic attractiveness. The latter case allows to divide the EU member states into de facto host and transit countries. In this context, Romania-considered as one of the transit countries for migrants heading to Western Europe-developed a set of policies, that in line with the acquis communautaire, render Romania prepared for the possibility of irregular migration. Against this conceptual background, the authors examine to what extent asylum policy implemented in Romania may benefit from improvements.

Haller et al. [31] in their paper titled 'International Migrant Remittances in the Context of Economic and Social Sustainable Development. A Comparative Study of Romania-Bulgaria', discuss migration as it is experienced by Bulgaria and Romania. The authors focus on economic determinants and implications of migration. To this end, such factors as inflation rate, GDP growth, GDP growth rate per 
capita, remittances received/capita are examined. The findings suggest that there is a direct relationship (negative and with average intensity) between the remittances received/capita and price inflation rate in Romania but not in Bulgaria. In the case of Romania and Bulgaria, the results indicate that there is a direct relationship with a similar intensity between the remittances received/capita and the unemployment rate, the household final consumption and income inequality.

Focusing on economic determinant of migration, Yüksel et al. [32] explore the specificity of migration in Azerbaijan. The authors collect annual data of 11 explanatory variables for the period of 1995-2015 and apply the Multivariate Adaptive Regression Splines (MARS) method to examine them. The research results show that people prefer to move to other countries in case of high unemployment rates. Furthermore, migration levels increase in times of population growth and increased mortality rates.

The question of economic determinants of migration, specifically in a Chinese context, are discussed by Fan et al. [33]. In their paper titled 'The Spatio-Temporal Characteristics and Modeling Research of Inter-Provincial Migration in China'. The authors examine national census data from two periods 1995-2000 and 2005-2010 to identify spatio-temporal characteristics of inter-provincial population migration in China. The findings of this research highlight that inter-provincial population migration increases rapidly in size with strong geographical proximity, however, China's inter-provincial population migration is still nascent. Statistically, inter-provincial population migration is negatively correlated with the level of economic development in the emigrant place and the migration distance and positively correlated with the level of economic development in the immigrant place and the population scale in the emigrant and immigrant places.

While the authors of the following paper [34] also examine factors determining people's decision to leave their habitat, the key focus of their discussion is that of de facto involuntary domestic migration in China. In their paper 'Exploring the Determinants of Migrant Workers' Willingness to Buy Houses in Cities: A Case Study in Xi'an, China', Zhang et al. [34] explore the real estate market in Chinese cities. Interestingly, by examining it through the lens of incoming migrant population and their house purchases' decisions, the authors shed light on an underdiscussed in the literature process of social engineering taking place in China today. Whereas the authors focus on the housing market and, to this end, utilize a logistic regression model with the data collected from 410 migrant workers in Xi'an, tacitly, the content of the paper showcases a very important, albeit underdiscussed facet of migration.

The Special Issue closes with a contribution that addresses questions pertinent to the social-psychology of migration [35,36]. In their paper titled 'Post-traumatic Stress Disorder and Social Isolation among North Korean Refugee Women in South Korea: The Moderating Role of Formal and Informal Support', Ryu and Park [37] explore post-traumatic stress disorder (PTSD) in context of migration. The authors argue that while there is abundant literature on the positive correlation between refugee PTSD and social isolation, few studies examine the moderating effects of formal and informal interpersonal support. The paper offers therefore an insight into this issue. Drawing from a careful analysis of primary date, the findings of the paper will be of great use to policy-makers when designing early proactive interventions to reduce the social isolation refugees.

\section{Conclusions}

The debate on migration flourishes. The burgeoning literature on diverse aspects of migration attests to that [38-40]. As it is always the case with research agendas that experience a boom, it is necessary that the conceptual precepts of the debate consolidate, while its metatheoretical foundations are taken seriously. In the same manner, it is necessary that topics of exploration are not the outcome of haphazard choices; rather, that they systematically bring together empirical concerns and considerations and conceptual frameworks. In this vein, this Special Issue, somewhat implicitly makes a case that much more work needs to be done to trigger the momentum for the inclusion of ICT in migration research. In times of the 4 th industrial revolution, in times of profound advances in ICT, the nexus between ICT and migration needs to be taken seriously. 
Author Contributions: All authors contributed equally to this paper. All authors have read and agreed to the published version of the manuscript.

Funding: This research received no external funding.

Conflicts of Interest: The authors declare no conflict of interest.

\section{References}

1. Visvizi, A.; Pachocka, M.; Lytras, M.D. Managing International Migration: Rethinking Transaction Costs. Red Tape, and Their Impact. Int. Migr. 2019, 57, 271-279. [CrossRef]

2. Pisarevskaya, A.; Levy, N.; Scholten, P.; Jansen, J. Mapping migration studies: An empirical analysis of the coming of age of a research field. Migr. Stud. 2019. [CrossRef]

3. Crawley, H.; Skleparis, D. Refugees, migrants, neither, both: Categorical fetishism and the politics of bounding in Europe's 'migration crisis'. J. Ethn. Migr. Stud. 2018, 44, 48-64. [CrossRef]

4. Pallister-Wilkins, P. Interrogating the Mediterranean 'Migration Crisis'. Mediterr. Politics 2016, 21, 311-315. [CrossRef]

5. Castles, S. Understanding Global Migration: A Social Transformation Perspective. J. Ethn. Migr. Stud. 2010, 36, 1565-1586. [CrossRef]

6. Goodman, S.; Kirkwood, S. Political and media discourses about integrating refugees in the UK. Eur. J. Soc. Psychol. 2019, 49, 1456-1470. [CrossRef]

7. Visvizi, A. On the fringe: Greece. migration, and populism. Rocz. Nauk Społecznych (Ann. Soc. Sci.) 2018, 46, 63-75. [CrossRef]

8. Lokshin, M.; Bontch-Osmolovski, M.; Glinskaya, E. Work-Related Migration and Poverty Reduction in Nepal. World Bank Policy Research Working Paper WPS4231. 2007. Available online: http://documents.worldbank. org/curated/pt/287551468053374058/pdf/wps4231.pdf (accessed on 14 December 2019).

9. Fernandez, N.T. Tourist brides and migrant grooms: Cuban-Danish couples and family reunification policies. J. Ethn. Migr. Stud. 2019, 45, 3141-3156. [CrossRef]

10. Nurick, R.; Hak, S. Transnational migration and the involuntary return of undocumented migrants across the Cambodian-Thai border. J. Ethn. Migr. Stud. 2019, 45, 3123-3140. [CrossRef]

11. Loschmann, C.; Bilgili, O.; Siegel, M. Considering the benefits of hosting refugees: Evidence of refugee camps influencing local labour market activity and economic welfare in Rwanda. IZA J. Dev. Migr. 2019, 9. [CrossRef]

12. Romano, D.; Traverso, S. The Heterogeneous Impact of International Migration on Left-behind Households: Evidence from Bangladesh. Int. Migr. 2019, 57, 121-141. [CrossRef]

13. Kipgen, N. The Rohingya Crisis: The Centrality of Identity and Citizenship. J. Muslim Minority Aff. 2019, 39, 61-74. [CrossRef]

14. Ahluwalia, P.; Toby, M. The Rohingya Crisis: Another Failure of the International System. Soc. Identities 2018, 24, 291-292. [CrossRef]

15. Islam, M.S. Understanding the Rohingya Crisis and the Failure of Human Rights Norm in Myanmar: Possible Policy Responses. Jadavpur J. Int. Relat. 2019, 23, 158-178. [CrossRef]

16. Carling, J.; Collins, F. Aspiration. desire and drivers of migration. J. Ethn. Migr. Stud. 2018, 44, 909-926. [CrossRef]

17. Mooney, E.D. Towards a protection regime for internally displaced persons. In Refugees and Forced Displacement: International Security, Human Vulnerability, and the State; Newman, E., van Selm, J., Eds.; United Nations University Press: New York, NY, USA, 2003; pp. 159-180.

18. Chand, S.; Markowski, S. ANZ-Pacific Migration Governance System. Int. Migr. 2019, 57, 294-308. [CrossRef]

19. Gleeson, M. Protection Deficit: The Failure of Australia's Offshore Processing Arrangements to Guarantee 'Protection Elsewhere' in the Pacific. Int. J. Refug. Law 2019. [CrossRef]

20. Cantor, D.J.; Chikwanha, F. Reconsidering African Refugee Law. Int. J. Refug. Law 2019. [CrossRef]

21. Vogelaar, F. A Legal Analysis of a Crucial Element in Country Guidance Determinations: Country of Origin Information. Int. J. Refug. Law 2019. [CrossRef]

22. Hassan, S.; Visvizi, A.; Haira, M. The 'who' and the 'what' in international migration research: Data-driven analysis of Scopus-indexed scientific literature'. Behav. Inf. Technol. 2019. [CrossRef] 
23. Douglas, P.; Cetron, M.; Spiegel, P. Definitions matter: Migrants, immigrants, asylum seekers and refugees. J. Travel Med. 2019, 26. [CrossRef] [PubMed]

24. de Hoon, M.; Vink, M.; Schmeets, H. A ticket to mobility? Naturalisation and subsequent migration of refugees after obtaining asylum in the Netherlands. J. Ethn. Migr. Stud. 2019. [CrossRef]

25. Iqbal, K.; Peng, H.; Hafeez, M. Analyzing the Effect of ICT on Migration and Economic Growth in Belt and Road (BRI) Countries. Int. Migr. Integr. 2019. [CrossRef]

26. Oiarzabal, P.J.; Reips, U.D. Migration and Diaspora in the Age of Information and Communication Technologies. J. Ethn. Migr. Stud. 2012, 38, 1333-1338. [CrossRef]

27. Benítez, J.L. Salvadoran Transnational Families: ICT and Communication Practices in the Network Society. J. Ethn. Migr. Stud. 2012, 38, 1439-1449. [CrossRef]

28. Visvizi, A.; Mazzucelli, C.G.; Lytras, M. Irregular migratory flows: Towards an ICTs' enabled integrated framework for resilient urban systems. J. Sci. Technol. Policy Manag. 2017, 8, 227-242. [CrossRef]

29. Visvizi, A.; Lytras, M. Rescaling and refocusing smart cities research: From mega cities to smart villages. J. Sci. Technol. Policy Manag. (JSTPM) 2018. [CrossRef]

30. Vasile, O.; Androniceanu, A. An Overview of the Romanian Asylum Policies. Sustainability 2018, $10,1461$. [CrossRef]

31. Haller, A.P.; Butnaru, R.C.; Butnaru, G.I. International Migrant Remittances in the Context of Economic and Social Sustainable Development. A Comparative Study of Romania-Bulgaria. Sustainability 2018, 10, 1156. [CrossRef]

32. Yüksel, S.; Mukhtarov, S.; Mahmudlu, C.; Mikayilov, J.I.; Iskandarov, A. Measuring International Migration in Azerbaijan. Sustainability 2018, 10, 132. [CrossRef]

33. Fan, X.; Liu, H.; Zhang, Z.; Zhang, J. The Spatio-Temporal Characteristics and Modeling Research of Inter-Provincial Migration in China. Sustainability 2018, 10, 618. [CrossRef]

34. Zhang, X.; Qu, M.; Jin, Z. Exploring the Determinants of Migrant Workers' Willingness to Buy Houses in Cities: A Case Study in Xi'an, China. Sustainability 2018, 10, 62. [CrossRef]

35. Verkuyten, M. The benefits of studying immigration for social psychology. Eur. J. Soc. Psychol. 2018, 48, 225-239. [CrossRef]

36. Cabaniss, E.R.; Cameron, A.E. Toward a Social Psychological Understanding of Migration and Assimilation. Humanit. Soc. 2018, 42, 171-192. [CrossRef]

37. Ryu, W.; Park, S.W. Post-traumatic Stress Disorder and Social Isolation among North Korean Refugee Women in South Korea: The Moderating Role of Formal and Informal Support. Sustainability 2018, 10, 1246. [CrossRef]

38. Pachocka, M. The twin migration and refugee crises in Europe: Examining the OECD's contribution to the debate. Yearb. Inst. East-Cent. Eur. 2016, 14, 71-99.

39. Parkes, R. Nobody Move! Myths of the EU Migration Crisis, Chaillot Paper N ${ }^{o}$ 143-December 2017; EU Institute for Security Studies Paris. 2017. Available online: https://www.iss.europa.eu/sites/default/files/EUISSFiles/ CP_143_Migration_0.pdf (accessed on 14 December 2019).

40. Pachocka, M.; Visvizi, A. Rethinking the Twin Migration and Refugee Crises in Europe through the Lens of Safety and Security. In The European Union and the Eastern Partnership, Security Challenges; Pacheco Amaral, C.E., Cucurescu, V., Gabrichidze, G., Horga, I., Kruglashov, A., Latoszek, E., Pachocka, M., Eds.; ECSA: Chișinău, Moldova, 2018; pp. 453-470. ISBN 978-9975-56-534-9.

(C) 2019 by the authors. Licensee MDPI, Basel, Switzerland. This article is an open access article distributed under the terms and conditions of the Creative Commons Attribution (CC BY) license (http://creativecommons.org/licenses/by/4.0/). 